\title{
White Protectionism in America
}

\author{
Rogers M. Smith and Desmond King
}

\begin{abstract}
Critics charge President Donald Trump with racism, but he insists he opposes bigotry and is an American nationalist, not a white nationalist. We use analysis of Trump's campaign rhetoric, his administration's policies, and their reception to assess these rival claims. In his campaign, Trump narrated American identity as a tale of lost greatness in which a once-unblemished America gave way to globalist elites who have victimized many Americans, particularly traditionalist, predominantly white Christian Americans. His policies have systematically expanded protections for such Americans and sought to increase their share of the American electorate and citizenry, while reducing or eliminating initiatives designed to assist and increase the numbers of non-white, nonChristian American voters and citizens. The evidence thus shows that although Trump does not explicitly endorse white nationalism, his rhetoric and policies articulate not a consistent race-blind nationalism, but a vision of white protectionism.
\end{abstract}

V hen President Donald Trump tweeted that African American Congresswoman Maxine Waters was "extraordinarily low IQ," he invoked a demeaning white supremacist trope (Trump 2018). But when PBS correspondent Yamiche Alcindor asked the president whether his embrace of the term "nationalist" risked being heard as a call for "white nationalism," Trump dismissed the very question as "racist" (Scott 2018). Trump proclaims that he opposes bigotry in all its forms; that he has done more than any other president for African Americans; that his nationalism embraces all Americans; and that it opposes only a "globalism" that refuses to put America first (Trump 2016d; Camera 2019).

Is Trump, despite his disavowals, a proponent of white nationalism? Is he instead an opponent of bigotry who, like many conservatives, is committed to color-blind policies? Or does he hold an emergent third position: is he a leader who promises to "protect" whites against a rising tide of unjust treatment (Jardina 2019, 45, 61)?

Analysis of Trump's rhetoric and policies supports the third hypothesis. Trump is neither an explicit white nationalist nor a true adherent to color-blindness. He is instead a white protectionist. That stance is significant. By remaking the modern Republican Party in his image, Trump has become the leader of modern racial conservatives. Since the 1970s, the latter have supported colorblind policies to prevent what they see as unjust racial harms (Bonilla-Silva, 2017; King and Smith 2011, 16-28, 117, Lieberman et al. 2019, 474-75). Critics of what we have called the "color-blind policy alliance" have long contended that this insistence on ignoring racialized identities makes anti-discrimination efforts impossible and perpetuates white advantages (Golub 2018, 6-7; King and Smith, 2011, 113-114). Trump, however, is changing the racial policy game. By portraying more traditionalist whites as victims of liberal measures favoring people of color, Trump is shifting the core of racial conservativism away from color-blindness toward policies designed directly to protect whites, including unconstrained policing, weakened civil rights enforcement, and franchise and immigration restrictions. Instead of simply vetoing raceconscious measures in the name of treating people without

Rogers M. Smith (D) is the Christopher H. Browne Distinguished Professor of Political Science at the University of Pennsylvania (rogerss@sas.upenn.edu).

Desmond King is the Andrew W. Mellon Professor of American Government at Nuffield College, Oxford University (desmond. king@nuffeld.ox.ac.uk). In addition to many other works, they have collaborated on numerous articles and one book, Still a House Divided: Race and Politics in Obama's America (Princeton University Press, 2011).

Rogers Smith expresses thanks to numerous colleagues at the University of Pennsylvania and Johns Hopkins University for excellent comments on earlier drafts of this paper. Desmond King thanks colleagues attending APSA panels and seminars at Northwestern University, the University of Melbourne, and Waseda University for excellent comments on earlier versions of this paper. Responsibility for errors lie with the authors. 
regard to race, the re-centering of racial conservatism facilitated by Trump stresses active measures to protect those deemed white against perceived inequities.

"Whiteness" is an "ever-morphing social category" that is "continually constructed" within "patterned sets of expectations, obligations, and accountabilities" shaping how identities are conceived (Hughey, 2016, 213). This shift toward white protectionism may convince some to embrace conceptions of white identity more fully, even as others are repelled. At the same time, Trump's championing of measures to protect most whites, while professing to treat all equally, may also reshape what we have termed the rival "race conscious" policy alliance opposed to color-blindness. Many in this alliance are now even more suspicious of allegedly universalistic programs and more insistent on race-targeted initiatives like reparations-thereby heightening policy polarization. Trump appears at best indifferent to the polarizing consequences of his rhetoric and policies, and often seems to welcome them.

\section{Theoretical Premises: Racial Policy Alliances and Racial Constructions}

We build on our claim that American politics has always been shaped by contests between rival racial policy alliances, from slavery and anti-slavery coalitions, through proponents and opponents of Jim Crow segregation and disfranchisement, to post-1970 debates over color-blind and race-conscious policies (King and Smith 2005, 2011). We now contend that the political forces that Trump now leads are reshaping those alliances, in ways that modify not just policy disputes but even conceptions of racial identities themselves. For the latter, we build on scholarship contending that political processes and agents contribute not only to the salience and expression but to the construction of racial identities (e.g. Omi and Winant 1986; Dawson and Francis 2015; Masuoka 2017, 6-8, 176; Brubaker 2017, 361-362, 373-374). W.E.B. Du Bois argued in 1920 that the "discovery of personal whiteness" was "a very modern thing, a nineteenth and twentieth century matter" that was becoming a "new religion of whiteness" in his time (Du Bois 1920, 29-30). Such "discoveries" occur in part because political entrepreneurs use resonant language to compose narratives defining political identities, including racial identities, and labeling some identities meritorious (Charland, 1987, 133-150; Brown 2006; Smith 2003, 2015). If successful, leaders then enact policies that make those identities central to the everyday lives of those they govern.

Donald Trump is such an entrepreneur. It is vital to grasp just how he is defining racial identities in his rhetoric and constructing them through his policies. Though Trump has certainly encouraged white nationalists, that label does not capture his politics fully. If he were simply reviving the white nationalism of earlier Americans like Andrew Jackson, whom Trump admires, he would make the direct claims to white superiority that were common in American political life up through the 1960s. Despite his many remarks critical of members of racial minority groups, Trump has never done so, insisting he deplores doctrines of white supremacy (Crowley and Haberman 2019). Outsiders cannot judge whether Trump is a white nationalist at heart, but unlike an Albert Beveridge or a George Wallace, he is not one in his explicit rhetoric.

It is more difficult to distinguish between the hypothesis that Trump is sustaining conservative support for colorblindness and the hypothesis that he is shifting to an emphasis on white protectionism. Though he has not used the terms "color-blind" or "white protection," he has not disavowed either one and he has made statements consistent with both. Furthermore, color-blind policies do protect many entrenched white advantages, a source of such policies' support. Yet the two positions point to three distinct observable implications for both rhetoric and policies.

First, the rhetoric of white protectionism highlights not the principle of color-blindness, but presentations of many whites as especially deserving of governmental aid and support - if not because whites are superior, then because whites are unjustly victimized. Second, unlike color-blind initiatives, policies of white protectionism weaken even facially race-neutral civil rights regulatory measures aimed at preventing discrimination against non-whites in arenas such as policing, housing, education, and employment (King 2007, Fergus 2018, Thurston 2018). Third, the demography of twenty-first-century America means that white protectionist goals, again unlike color-blind ones, imply the desirability of actively restricting immigration to reduce growth in the non-white share of the U.S. population, and restricting voting to reduce growth in the non-white share of the electorate.

\section{Summary of Core Claims}

While not the first to promote these positions, Trump and those he has mobilized do so more effectively than any others in recent American politics. In rhetoric, Trump's campaign speeches first present the nation's past as unequivocally great, minimizing past, much less present, racial discrimination and white supremacist traditions. Second, Trump portrays many Americans today as victims of the secular "globalist" policies of corrupt elites who aid opponents of "Americanism," many with foreign origins and religions, while disadvantaging those most committed to American values, especially traditionalist Christians, who are predominantly white. Repurposing liberal multicultural themes, Trump insists that the lovers of America deserve to have their identities protected like other identity groups, if not more so, since the U.S. government has a duty to put Americans first. Trump may tell himself that he treats all Americans as equals, as proponents of color-blind policies maintain. However, public opinion research, voting behavior, and extremist group mobilizations all confirm that his 
rhetoric has appealed most to those Americans who have felt their ways of life threatened in a changing America, especially conservative white Christians (see, e.g., Democracy Fund Voter Study Group 2017; Sides, Tesler, and Vavreck 2019). They are the heroes of his story of America.

In office, moreover, Trump has adopted policies to aid his core constituents that go further than his rhetoric to protect the privileged status of white Christians, and all those regarded as white in America. Given that who counts as "white" is a continuing political construction, we cannot dismiss the possibility that white protectionist policies, which fall short of explicit white nationalism but go beyond a principled, consistent color-blindness, may attract strong support from American electorates in the years ahead (Alba 2016).

As evidence for these claims, we first map two converging trends. These are the rising visibility of Donald Trump as a public figure keen to oppose African Americans' concerns, and the convergence of numerous disruptions that have led many white Americans, especially white Christian Americans, to feel they face unjust threats. We then document how Trump's campaign rhetoric formulated the themes just summarized into a dramatic story of embattled American identity. Next we detail how Trump's policies are rewarding his followers, especially whites, by strengthening their capacities to protect their interests, weakening civil rights initiatives that aid non-whites, and buttressing the numerical predominance of whites in the population and the electorate. Finally, we consider the role of the Trump movement in bolstering senses of white identity in some voters, in stimulating white nationalist activism, and in propagating white protectionist candidates.

How far these trends protect and extend white privileges may be the most important question in American politics today.

\section{The Emergence of Donald Trump}

In prior careers as a real estate developer, reality show star, and brand marketer, Donald Trump used his public statements and actions to court celebrity more than consistency. Often he took liberal positions. Yet more than most, Trump gained notoriety for speaking and acting in ways that he proudly proclaimed not to be "politically correct." In the 1970s, the Justice Department accused Trump and his father Fred of violating the Fair Housing Act by discriminating against renters of color, though the Trumps claimed they merely fenced out undesirables. The charges went unresolved. In 1989, Trump took out ads denouncing the "Central Park Five" accused, falsely, of assaulting a jogger. Even after their exoneration, Trump depicted them with language many judged racially derogatory. In 2000, Trump paid fines for funding ads portraying Native Americans as irresponsible casino owners (though he also opened up Mar-a-Lago to all groups). In 2011, after he won a large fan base through his books and television shows, Trump gained far more attention by boasting he would prove that Barack Obama had not been born in the U.S.A. He never did. Trump finally abandoned the claim after his 2016 presidential nomination, though many Republicans with high racial resentment scores still believed it (Jardina and Traugott 2019, 71). By then, Trump's criticisms of African Americans and Latinos as dangerous criminals were commonplace (Desjardins 2017).

These well-publicized stories, especially Trump's birther role, meant that after 2012 most Americans knew Donald Trump as a flamboyant celebrity who was far more willing than most to maintain even disproven charges that people of color posed threats to whites. As the 2016 presidential campaign began, 92\% of Republican-leaning voters felt familiar enough with Trump to have an opinion on him, more than for any other candidate; $56 \%$ were favorable, though 36\% were not (Duggan 2015). Most of the leadership of both parties did not take him seriously. Tens of millions of Americans did.

\section{The Perfect Storm for Trump}

Like voters elsewhere, by 2016 many Americans were growing receptive to leaders promising protectionist policies. In many lands, traditionally dominant groups, including racial groups, were experiencing what Gest, Reny, and Mayer call "nostalgic deprivation," defined as "a perceived threat to or loss of status - a sense of social, political or economic deprivation" $(2018,1699)$. Increased numbers of immigrants, often ethnoculturally distinct from national majority populations and sometimes unauthorized, were a common trigger (Ivarsflaten 2008; Gest 2018). Antimigrant sentiment was frequently augmented by alarming economic changes, including heightening economic inequalities, the outsourcing of jobs, stagnant middle-class wages, reliance on foreign financiers, and trade deals perceived as unfair, all combined with subordination to international organizations like the WTO, the World Bank, the IMF, the EU, and NAFTA (Margalit 2012). In many locales, some members of dominant groups also felt threatened by emancipatory movements for long-marginalized populations, including racial, ethnic, linguistic, and religious minorities, indigenous peoples, LGBTQ + communities, and the disabled (Brubaker 2017, 371-372). Many sought malefactors to blame (Gest, Reny, and Mayer 2018, 1712).

Donald Trump spoke vociferously to all these concerns in ways that catapulted him to the head of a national movement. He began his campaign by denouncing most people Mexico was "sending" to the United States as dangerous. He called for repudiating NAFTA, the TransPacific Partnership, and other American trade agreements. He promised a ban on Muslim immigrants to combat terrorism, while pillorying "political correctness," usually interpreted to mean redress for long-disadvantaged groups. He especially championed Christian evangelicals, and he claimed to speak more generally for "forgotten" Americans. 
Trump won against the will of the GOP establishment, moreover, because in the United States as elsewhere, public distrust of established politicians and institutions had been growing for decades, with political parties increasingly displaced as the chief agencies for channeling political loyalties and actions, including choosing candidates. The reliance on primaries since the 1970s orchestrated this displacement, aided by new social media that enable candidates to communicate directly and frequently with their mass constituencies (Brubaker 2017, 369-370). Trump won impressive primary victories over a fragmented field in part via incessant tweets to his vast Twitter following, either to circumvent mainstream media messages or to drive their content (Schroeder 2016).

Trump exploited America's distinct version of "nostalgic deprivation." The nation's political polarization centers in part upon partisan polarization over racial issues (King and Smith 2014, 968; Tesler 2017). As this division has deepened, many whites have come to feel that they, rather than people of color, are the primary victims of unjust discrimination in America. A 2011 study found that while both black and white Americans believed anti-black bias declined from 1950 through 2000, many whites thought anti-white bias had been rising, coming by 2000 to be more extensive than anti-black bias (Norton and Sommers 2011). In 2016, more Trump voters saw whites as discriminated against than they did any other group; most believed that it was "average Americans," not African Americans, who were now getting less than they deserved (Edwards-Levy 2016; Tesler 2017). In 2017, another survey found that $55 \%$ of whites believed that whites suffer discrimination in America (Gonyea 2017). Those who view whites as discriminated-against often cite raceconscious policies in employment and education as examples. While professing to favor color-blindness, some oppose even facially neutral policies that they see as intended chiefly to assist non-whites (Tesler 2012, 2016).

As Trump has emboldened opponents of civil rights enforcement, some proponents of race-conscious policies have grown more adamant in return, concluding that calls for "universalistic" or "color-blind" policies simply urge neglect of racial inequalities. Those contentions inform the debate over whether it is wrong to replace Black Lives Matter with All Lives Matter, with the latter accused of expressing desires to focus only on whites (Cargle 2018). Some progressives fear that stressing universalistic policies like Medicare for All will dilute needed attention to race-conscious measures. Consequently, overt willingness to advocate for reparations to aid African Americans surged as the nation approached the 2020 campaign (Jamerson 2019). Conservatives have seized on that heightening polarization as proof that whites are under threat today.

The gathering of these storms in the United States formed a climate open to populist thunderbolts hurled at prevailing economic, national security, immigration, and education policies, and at the mainstream media. Trump won support by advancing all those critiques, and he added attacks on allegedly rising crime rates and denunciations of those who call for police restraint in dealing with suspects, generally black or Latino. He traced the nation's problems to corrupt politicians like Hillary Clinton, who he charged - with some evidence - get payoffs from global economic elites, in return for favoring those elites above everyone else. Trump did not specify just who "the people" were that these elites had endangered, and he used themes about economic and securitarian threats common to populists elsewhere (Brubaker 2017, 366). Few analysts doubt, however, that to Trump supporters, protecting "average Americans" predominantly means protecting white Americans. Data from the American National Election Studies shows that during the Obama years, many more self-identified white Americans came to say that their white identities were "extremely" important to them (Gest 2018, 38-39; Jardina 2019, 61). Voters embracing white identity overwhelmingly supported Trump (Sides, Tesler, and Vavreck 2017, 16; Jardina 2019, 234, 236-238).

Using public opinion data, Jardina contends that, though white voters who score high on racial resentments are Trump's strongest supporters, many others who value white identity chiefly display concerns to protect their racial in-group, not hostility to others. Nonetheless, this second, larger group of whites still largely favors Trump (Jardina 2019, 33-34, 43-45, 82, 232, 236). Her data did not permit her to study the construction of white identities over time, nor to examine Trump's rhetoric and policies in detail $(45,61)$. But she posits, consistent with the arguments here, that "politicians can activate white identity ... by drawing attention to potential threats to whites' status and campaigning to protect that status" (43).

\section{Trump's Campaign Rhetoric}

When he announced for president, Donald Trump was a veteran public speaker but an untested politician. His message evolved during the course of the 2016 campaign, often in response to what his audiences cheered. Still, his June 16, 2015, speech announcing his candidacy made plain the two themes of the story of America that frames all his positions.

Trump lamented that America "used to have victories," but "we don't have victories anymore"; and he ended with his trademark promise, that "we will make America great again" (Trump 2015). Neither then nor later did Trump give much attention to ways in which America may not have been great in the past. Instead, he urged a foreign policy designed "to reinvigorate Western values and institutions" by "promoting Western civilization and its accomplishments" (Trump 2016a). To many, "Western" civilization means "white" civilization (Hood 2019). 
Trump maintained that "our American culture is the best in the world," and he insisted that "pride in our institutions, our history, and our values should be taught by parents and teachers and impressed upon all" (Trump 2016d). Occasionally Trump later indirectly noted the nation's history of racial discrimination, praising African Americans as having "lifted up the conscience of our nation in the long march toward civil rights," but he steadfastly blamed the modern difficulties of America's racial minorities on Democratic leaders, not on centuries of unjust treatment. Traditional "American values and cultures," required no rectification; they should instead be "cherished and celebrated once again" (Trump 2016f).

Trump's second theme was a jeremiad proclaiming that this once-great America had been plagued in recent decades by a corrupt ruling class. In his announcement speech, Trump attacked China, Japan, and especially Mexico and Islamic terrorism; but he contended that America's "leaders," who were "stupid ... losers ... morally corrupt," were the nation's biggest problem (Trump 2015). Trump accused recent leaders of surrendering the country to "the false song of globalism." Contending that the "nation-state remains the true foundation for happiness and harmony," he promised that "America first" would be his "overriding theme" (Trump 2016a). But in the United States, there were now "two Americas: the ruling class and the groups it favors, and then everyone else" (Trump 2016b). The "Washington establishment, and the financial and media corporations that fund it," were the "central base" of a "global power structure" that rewarded America's "corrupt political establishment" for welcoming cheap illegal immigrant labor, helping companies move jobs overseas, and cutting deals with countries that sponsored Islamic terrorism (Trump 2016k).

Liberal policies, Trump went on to insist, added cultural and violent physical victimization to the economic victimization many Americans were experiencing. Trump did not explicitly attack race-conscious policies like affirmative action, one of many issues on which he made conflicting statements prior to his candidacy. But Trump, who generally portrays issues in zero-sum terms, repeatedly made clear that he saw most efforts to assist long-discriminated-against minorities not as means of promoting equality but as dangers to those who America has traditionally protected (Schnurer 2017). He criticized Barack Obama for "speaking up about America’s past errors," instead of proclaiming America's superiority. Trump complained that concerns about "racial profiling" or calls for checks on severe policing and immigration measures meant that "political correctness has replaced common sense" (Trump 2016d). He excoriated "those peddling the narrative of cops as a racist force in our society" for "hurting" law-abiding Americans (Trump 2016e, 2016j). He tweeted accounts of, especially, white victims of crimes perpetrated by blacks, twice retweeting from a Twitter user called "WhiteGenocideTM" (Kopan
2016; Confessore 2016, Holmes 2017). What Trump termed his "new civil rights agenda for our time" featured strong policing, school choice, and deregulation to promote jobs-all policies presented without reference to race, thereby eschewing explicit white nationalism but also any efforts directly aimed at reducing racial inequalities (Trump 2016h). His proposals instead implied that the public needed to be protected against race-conscious measures and other liberal policies that only served globalist elites.

Trump promised to protect Social Security and Medicare, social programs more commonly perceived by whites as beneficial to them than as aid to minorities (Jardina 2019, 4, 191-194, 202, 234, 258; On the Issues 2019). Trump's most specific calls for protection came on behalf of Christians. His nomination acceptance speech criticized the 1954 Johnson amendment depriving "religious institutions" of their tax-exempt status "if they openly advocate their political views," saying their "voice has been taken away" (Trump 2016c). He went on to tell Christian groups that "Christian faith is not the past but the present and the future" of America. He contended that "our media culture often mocks and demeans people of faith," and that "our politicians have really abandoned you." Trump promised that in his administration "Christian heritage will be cherished, protected, defended, like you've never seen before" (Trump 2016g; Trump 2016i).

With greater consistency and scope than many analysts appreciate, these statements advanced a specific and, for many, compelling narrative of American peoplehood that paid off electorally. A wide variety of studies, including experimental research, public opinion surveys, analyses of voting statistics, and panel studies show that this victim narrative connected powerfully with those with strong attachments to traditionally dominant identities, including white, Christian, and male. Using panel data for 2012 and 2016, Mutz found that people whose orientation in favor of socially dominant groups (SDO) underwent increases during those years also considered whites as more discriminated against than racial minorities, Christians as more discriminated against than Muslims, and men as more discriminated against than women. Their sense that "the American way of life is threatened" was strongly associated with voting for Trump (Mutz 2018, E4332, E4334-6). Though Trump spoke most explicitly to those who believe in a dominant place for Christianity in America, recent scholarship shows that those who "who connect being Christian with being an American are also more likely to hold racial attitudes that bolster white supremacy" (Perry and Whitehead 2019, 280). Conversely, white identifiers are more likely to believe that "being Christian is important to being American" (Jardina 2019, 107, 125). One 2018 survey found that $54 \%$ of white evangelical Protestants thought it would be bad for America to become a non-white nation. They contribute signifcantly to the slight majority of white Americans who say the 
United States was better in the 1950s than today; the 56\% of whites who wish to limit immigration; and the growing number of Republicans who say America is a Christian nation (PRRI 2018).

Trump's rhetoric gave both white nationalists and believers in a Christian America renewed senses of legitimacy and opportunity during the primaries (Lopez Bunyasi 2019). White supremacist posts accelerated on a leading right-wing website, $4 \mathrm{Chan}$, from the time Trump announced his candidacy through 2018 (Thompson 2018). White nationalists like Richard Spencer and Jared Taylor rallied to his cause. Spencer believed that though Trump did not see himself as a white nationalist, he expressed "an unconscious vision that white people have- that their grandchildren might be hated in their own country" (Osnos 2015). He contended that Trump was "bringing identity politics for white people into the public sphere in a way no one has" (Confessore 2016). In 2016, Andrew Anglin of the neo-Nazi website Daily Stormer celebrated Trump's retweeting from the WhiteGenocide account by proclaiming, "Our Glorious Leader and ULTIMATE SAVIOR has gone full-wink-wink-wink to his most aggressive supporters" (Anglin 2016). As 2016 proceeded, champions of white identity including William Johnson, the chair of the American Freedom Party, and former Ku Klux Klan leader David Duke, contributed robocalls and other aid to Trump (Confessore 2016: Sides, Tesler, and Vavreck 2019). Rachel Prendergraft, an organizer for the Knights Party - a successor to the KKKmaintained that the "success of the Trump campaign just proves that our views resonate with millions .... They may not be ready for the Ku Klux Klan yet, but as anti-white hatred escalates, they will” (Lopez 2019). Though many white supremacists wish for Trump to go further, most have celebrated his presidency and become more outspoken.

Trump's inflammatory race-related statements may well stimulate other airings of prejudice (Schaffner, MacWilliams, and Nteta 2018). The Trump White House, to be sure, denies that he claimed that immigrants from Haiti have AIDS, that Nigerians come from huts, and that America needs immigrants from Norway, not "shithole [African] countries" - though former Trump aides have confirmed these stories (Lopez 2019). To admirers, Trump's criticisms of African American football players protesting police killings of young black men, and his characterizations of MS-13 gang members as "animals," express only support for law and order (Hayes 2018). Some regard even his claims that there were "some very fine people" on both sides at the Charlottesville white supremacy rally, and that "both sides" were to blame for the ensuing violence, as simply displaying his resistance to the demonization of traditionalist Americans.

But it is incontrovertible that Trump fiercely supported Senate candidate Roy Moore in Alabama, despite Moore's stating that America had been great in the days of slavery, because "families were strong, our country had direction" (Bump 2017). Trump praised Arizona sheriff Joe Arpaio for keeping "Arizona safe" and pardoned him after Arpaio was found guilty of criminal contempt for racially profiling persons he suspected of being illegal immigrants (Davis and Haberman 2017). Though Trump had partisan motives, his actions identified him with figures widely perceived as hostile to non-whites. He also won white nationalist applause when he tweeted that he had instructed Secretary of State Mike Pompeo to "study the South Africa land and farm seizures ... and the large scale killing of farmers," giving credence to false claims that the South African government was murdering white farmers (Sankin and Carless 2018). When Trump later tweeted that four first-term Representatives, all women of color, two Muslim, should "go back" to the "totally broken and crime infested" countries "from which they came," even Ted Cruz demurred from his "overheated" rhetoric (Summers 2019). These statements and more mobilized the two great narrative themes of Trump's campaign: that America was great in the old days (when it was a white Christian male-governed nation); and that good Americans, especially Christians, now face assaults from dangerous immigrants, foreign nations and religions, and unpatriotic elites. Having won power on a narrative of victimization, Trump has never ceased to advance it, in governing deeds as well as campaign words (Brownstein 2019).

\section{Trump's Actions and Policies}

President Trump's policies go even further than his rhetoric. We have previously documented the positions of the racial policy alliances in American politics. The color-blind alliance has not only opposed affirmative action programs in education and employment. Because many of the alliance's members have always had white protectionist concerns, they favor "tough on crime" policies, restrictive immigration measures, culling government efforts for racially integrated housing, school choice vouchers in place of integration orders, stricter tests for eligibility to vote, and opposition to districting aimed at empowering minority voters, among other measures (King and Smith 2011, 259-262). Researchers also find that many Americans' positions on racial policies correlate with positions on other issues that may not seem to concern race, including health care, tax policies, samesex marriage, and the economy (Tesler 2015, 104). In its first two years, the Trump administration acted aggressively on all these issues in ways that moved from merely upholding color-blindness to installing white protectionism. This change parallels Trump's shift of Republican economic policies from free trade to protectionism, and indeed, his rallies often suggest that the chief beneficiaries of his economic protectionism are more traditionalist white workers. 


\section{Appointments}

Despite unprecedented turnover, Trump's appointments have sent clear policy signals. His first Attorney General, Jefferson Sessions, once prosecuted Klan members, but Sessions also criticized affirmative action policies and complained without evidence about vote fraud (Levine 2016). In a 2015 interview with Stephen Bannon, Sessions praised the race-based national-origins quota system the nation adopted in 1924 and ended in 1965 (Serwer 2017). Bannon, formerly a top Trump adviser, professes to be anti-globalist but not white nationalist. Yet as chief executive of Breitbart News, he oversaw publication of white nationalist writers (Smith 2017). Stephen Miller, still a senior adviser, has similarly repudiated white nationalism and denied that Richard Spencer was a "mentor" to him at Duke. However, leaks of his e-mails in the years immediately preceding his joining the Trump campaign show that he publicized white nationalist views (Garcia-Navarro 2019; Rogers and DeParle 2019). In office he has been an ardent voice for severe immigration restriction measures, including the "Muslim ban" and family separations (Rogers and DeParle 2019; Hatewatch 2018). Miller is not alone. HUD added Eric Blankenstein to its general counsel's office despite the fact that he had previously been compelled to leave the Consumer Financial Protection Bureau after racist blogs he authored years before surfaced -blogs he dismissed as irrelevant to his duties (Fadula and Thrush 2019).

\section{Policies}

The signals sent by these appointments match Trump's policy enactments (figure 1). His measures adopt positions favored by racially conservative Americans but with a new focus on active white protection, rather than simply colorblind efforts to constrain positive governmental actions. Trump has fanned the anger of many white supporters convinced that post-1970 federal policies have unjustly favored people of color. Combatting this alleged white victimization requires protectionist measures including tolerating racial profiling in policing and reversing some extant civil rights policies, subverting others through deregulation or neglect, and favoring measures that go beyond color-blindness, such as stop-and-frisk practices and demands for identification triggered by racial and ethnic identities, as well as anti-Muslim immigration restrictions.

If this trend persists and continues to garner the support of voters who self-identify as white ethnics, then the Trump administration will prove to be an agent of major change to America's racial orders. Color-blind measures will be overshadowed by active white protectionist measures as the core of today's conservative racial policy alliance. They will be pitted still more sharply against the race-consciousor in Justice Sotomeyer's terms, "race sensitive"-measures

favored by the reformist policy alliance, perhaps generating more radical counter-assertiveness by its proponents.

With only highly qualified exceptions, the Trump positions summarized in figure 1 include most of the policies long preferred by racial conservatives, while adding policies that serve white protectionism. In many cases, administration actions go beyond what Trump said in the campaign or his later boasts in office. It is probable that the voters and activists who care most about these policies have taken note. They can see that Trump has sought to provide invigorated defenses and accommodations for anxious and angry members of his base, especially native-born white Christian Americans. Those who have hoped not just for color-blindness but for policies that bolster the positions of whites against unwanted changes have had reasons to feel satisfied.

A closer look at the policies listed in figure 1 shows why. Though Trump did not campaign against affirmative action programs, his Justice Department's Civil Rights Division soon prepared an initiative to sue universities suspected of emphasizing race in their admissions policies, including Harvard and Yale (Savage 2017). Attorney General Sessions assisted long-time affirmative action critic Edward Blum in bringing a lawsuit against Harvard's program (Alexander 2018). Similarly, Kenneth Marcus, since 2018 the head of civil rights enforcement in the Education Department, previously worked with groups filing briefs against affirmative action (Green, Apuzzo, and Benner 2018; Chen 2018). Both departments have rescinded Obama-era guidelines for legally achieving greater diversity and have prodded educational institutions to abolish many such policies. The Trump administration briefly challenged the constitutionality of the HBCU Capital Initiative Fund, before deciding to increase funding for HBCUs (Historically Black Colleges and Universities) while reducing funding for low-income students at all higher education institutions (Camera 2019). Though some leaders of HBCUs have celebrated their funding increases, the policies are consistent with the administration's refusal to pursue racial integration goals.

In civil rights enforcement more generally, the Trump administration's stance mirrors Trump's campaign theme, that religious Americans, especially traditionalist ones who are predominantly white, are the greatest victims of discrimination today. Attorney General Sessions made mistreatment of religious groups the Justice Department's highest priority. The DOJ provided guidelines for all executive agencies to insure they did not violate "religious liberty protections", forcefully pursued litigation on behalf of religious groups, and created a Religious Liberty Task Force so that "our employees know their duties to accommodate people of faith" (Sessions 2018). A "Conscience and Religious Freedom Division" in the Office of Civil Rights seeks to permit health care providers to refuse treatment to certain patients on religious grounds (Leadership 


\section{Figure 1}

Trump policies and priorities of racial conservatives.

\section{Affirmative Action}

- Justice Department initiated investigations of Harvard and other universities' affirmative action policies (Savage 2017); sided with litigants challenging Harvard's affirmative action program (Alexander 2018)

- Departments of Education and Justice issued joint letter to universities rescinding seven Obama affirmative action guidelines for advocating "policy preferences and positions beyond the requirements of the Constitution" (Green, Apuzzo, and Benner 2018)

- Administration challenged constitutionality of HBCU Capital Investment Fund, reduces support for lowincome students, while increasing overall funding for HBCUs (Camera 2019)

- Supreme Court nominee Brett Kavanaugh formerly condemned affirmative action for minorities, though said he sought to hire women law clerks (Jaschik 2018)

\section{Civil Rights Enforcement}

- Justice Department prioritized religious freedom over other civil rights (Sessions 2018)

- EEOC ended rule requiring companies to report employee pay by sex, race, and ethnicity to identify discriminatory pay patterns (Mann 2017)

- Consumer Financial Protection Bureau's Office of Fair Lending and Equal Opportunity lost enforcement powers against discrimination in lending (Berry 2018)

- Funding cut for investigations of white nationalist groups; FBI investigations reduced despite increases in white supremacist crimes (Beinart 2018; Einbinder 2019)

- Education Department delayed Individuals with Disabilities Education Act rule limiting disproportionate treatment of minority students with disabilities (Office of Special Education and Rehabilitative Services 2018)

- Veterans Affairs diversity officer told not to condemn white nationalists (Rein 2018)

- Justice Department held 1964 Civil Rights Act does not protect against workplace discrimination of transgender persons (Moreau 2018)

- Justice Department initiated review of disparate impact regulations (Meckler and Barrett 2019)

\section{Immigration}

- Officials criticized 1965 reform ending national origins quotas for immigration (Miroff 2018)

- President imposed travel ban on predominantly Muslim nations (Gladstone and Sugiyama 2018)

- Imposed case quotas for immigration judges to facilitate deportations (Sacchetti 2017)

- Pardoned former Arizona sheriff Joe Arpaio (Davis and Haberman 2017)

- Rescinded DACA program (National Immigration Law Center 2019)

- Curbed grants to sanctuary cities, with threats of further sanctions (Leadership Conference on Civil and Human Rights 2018)

- Terminated Temporary Protected Status for Nicaraguans, Haitians, Salvadorans, Nepalese and Hondurans in the U.S (Leadership Conference on Civil and Human Rights 2018)

- Terminated eligibility of Haitians for H2-A and H2-B visas (Torbati 2018)

- Created task force, office to investigate naturalizations (Wessler 2018; Benner 2020)

- Deployed military troops to prevent immigrant caravans (Gutierrez 2018)

- Shut down government, transferred funds to construct wall using emergency powers (Paletta, DeBonis, and Wagner 2019)

- Imposed fees, other requirements on asylum seekers (Sachetti, Sonmez, and Miroff 2019)

- Considered reduction in overall immigration levels, point systems (Baker 2017) 


\section{Figure 1 (continued.)}

\section{Voting}

- Created commission to investigate alleged vote fraud (Ingraham 2016)

- Justice Department supported state efforts to enforce tougher voter ID requirements (Public Interest Legal Foundation 2018a)

- Justice Department supported Ohio's registration roll-clearing law; sued Kentucky to compel it to purge its rolls (Liptak 2018; Sanders 2018)

- Proposed new citizenship question on census, risking accuracy (Public Interest Legal Foundation 2018b)

\section{Policing}

- Justice Department sought to reverse consent decrees reforming practices of twenty city police departments (Bosman and Smith 2017)

- Attorney General curbed further use of reformist consent decrees (Benner 2018)

- Attorney General ended ban on transfer of military equipment to police forces (Viswanatha 2017)

- Justice Department stopped new investigations into police shootings (Lowery 2018)

- Justice Department's Civil Rights Division's Special Litigation Section, responsible for police investigations, downsized (Reilly 2019)

- President expressed support for stop-and-frisk by police in U.S. cities (Rucker 2018)

- Office of the Community Oriented Policing Services (COPS) closed (Reilly 2019)

- President signed bipartisan First Step Act, providing sentencing relief, rehabilitation programs to reduce mass incarceration (Trump 2019)

\section{Housing}

- Justice Department and HUD stopped Fair Housing Act disparate impact suits (Arpey 2017)

- HUD proposed rule change to preclude disparate impact review (Furman Center 2019)

- HUD suspended Obama-era rules against barriers to housing choice (Arpey 2017, Furman Center 2018)

- HUD suspended programs varying rent subsidies with regional wealth (Hall 2017)

\section{Schools}

- Education Department created grant program to promote private school vouchers (Strauss, DouglasGabriel and Balingit 2018)

- Justice Department limited federal monitoring of integration plans and urged releases from court desegregation orders (Hannah-Jones 2017; Felton 2017)

- Education Department revoked guide for reducing racial biases in school discipline (Ujifusa 2018)

- Education Department rescinded guides for addressing campus sexual misconduct and protecting transgender students, students with disabilities (Office of Civil Rights, DoE 2017; Bayer 2017)

\section{Welfare Reform}

- Proposed work requirements for Medicaid and SNAP program recipients, with some exemptions for primarily rural white counties (Covert 2018)

- Executive order imposed other new work requirements, called for developing more (Andrews 2018)

- FCC sought to limit providing phone and internet to low-income and tribal areas (Morris 2018) 
Conference on Civil and Human Rights n.d.). Attorney General William Barr has continued Sessions' prioritization of religious liberty, contending that "secularists" have been using law "as a battering ram" in "an unremitting assault on religion and traditional values" in ways that the Justice Department was "ready to fight" (Barr 2019).

As Barr's stance showed, this agenda has not always succeeded. Though Trump boasted that he ended the Johnson Amendment by executive order, in fact the legislative ban on endorsing candidates persists. The Trump administration has therefore mobilized religious leaders to get Congress to overturn the law, but so far, these efforts have failed (Dias 2017). Still, religious conservatives cheered when Trump's Justice Department urged the Supreme Court to rule that the Civil Rights Act does not protect transgender persons (Moreau 2018). Trump's Supreme Court appointments Neil Gorsuch and Brett Kavanaugh have provided added reassurance by showing their eagerness to hear claims that religious liberties of conservative Christians are being abused (Weber 2019; Salozar 2019).

The Trump administration has ended federal grants to groups working to oppose white nationalism (Raymond 2017; Beinart 2018). Though Trump announced that monitoring anti-white nationalists would increase after a white supremacist's shootings in El Paso, Texas, in fact they have declined (Einbinder 2019). The Trump administration has focused domestic anti-terrorism efforts on Muslim groups, even though white supremacists have committed more than three times as many violent crimes and murders in the United States in recent years (Reitman 2018). A Veterans Administration official even discouraged the agency's diversity officer from condemning white nationalists (Desjardins 2017).

Trump officials eliminated an Equal Employment Opportunity Commission requirement for large companies to disaggregate employee pay scales by sex, race, and ethnicity, hampering anti-discrimination efforts. A federal court overturned that action (Schmidt 2019). Other Trump appointees cut back on the enforcement authority of the Consumer Financial Protection Bureau's Office of Fair Lending and Equal Opportunity and delayed a rule to protect racial and ethnic minority students with disabilities against disproportionate adverse treatment. At this writing Trump's Education Department is considering eliminating all rules focused on racially and ethnically disparate impacts. The Trump administration has not eliminated the offices of civil rights created in most federal agencies in the late 1960s, which monitor hiring, promotions, and discrimination among employees. However, it has shifted authority in these offices from career civil service employees to political appointees, changing the ethos of enforcement (Savage 2017).

The Trump administration's immigration policies powerfully signal its protectionist themes by working to limit the growth of the non-white population. Trump has fervently pressed to build a wall along the nation's southern border, even if this requires shutting down the government or making disputed constitutional claims to emergency powers. That quest has yet to succeed, and his effort to rescind the DACA program benefiting some unauthorized immigrant children is tied up in litigation (National Immigration Law Center 2019). But the agenda is clear.

Trump did arrive at a judicially acceptable executive order restricting travel to the United States from citizens of six predominantly Muslim nations, to which he later added four African and two Asian countries. His administration has also terminated Temporary Protected Status for persons from four Central American nations as well as Nepal, and it has ended the eligibility of Haitians for visas used primarily by low-skilled workers. It has deployed over 5,000 military troops to the southern border, and it created first a task force, then a new office in the Department of Justice, to withdraw naturalizations from foreignborn Americans, even in cases of minor misstatements in naturalization documents (Benner 2020). These measures all signal that Latinx and Muslim immigrants are not welcome in Trump's America.

Similarly, Trump's message of protection for some shapes his policies on voting rights. Trump appointed Kansas Secretary of State Kris Kobach, a leading alarmist about alleged vote fraud and an architect of anti-immigration laws, to head a commission to investigate fraudulent voting (Ingraham 2017). It found little evidence of any. Disbanded in January 2018, the commission's mandate was transferred to Homeland Security (Tackett and Wines 2018).

Still, the Trump Justice Department frequently files briefs in support of state measures restricting voting. It has urged aggressive purges of voter rolls by state election boards, the redrawing of political boundaries that dilute African American voting rights, and stringent photo ID registration and voting requirements. It joined a suit against Kentucky to compel the state to cull rolls of voters who had moved, and supported a similar effort in Ohio (Wines 2018). The Justice Department and the Immigration and Customs Enforcement agency have also coordinated requests to states for data on voter records: millions of North Carolina records have been subpoenaed from the state elections board and forty-four county elections boards, including many with low-income voters of color (Faussett and Wines 2018). Political appointees, not career lawyers, lead these actions.

In close elections, these vote suppression measures have great partisan and racial significance. In the 2018 Georgia gubernatorial race, the successful GOP candidate ran while serving as Georgia's Secretary of State (Herndon 2018). In that capacity, Brian Kemp used the state's obscure "exact-match law" to excise over 50,000 voters for differences between a registered name and a signed name. African Americans, 32\% of the state's population, 
composed $70 \%$ of the registrants affected (Cobb, 2018). Even prior to that purge, the Brennan Center for Justice estimated that under Kemp, 1.5 million voters in Georgia have been removed from the rolls (Herndon 2018). The Center also reported that in 2017, after Trump's victory, thirty-one state legislatures introduced ninety-nine bills to reduce voter access (Brennan Center for Justice 2017).

Many of those measures have met stiff opposition. In November 2018, Florida voters approved a constitutional amendment to restore voting rights to over one million ex-felons, though the state's Republican governor and legislature have blocked its full implementation by insisting that ex-felons must pay all outstanding fees to the legal system before voting (Stein 2018; Mazzei 2019). A related controversy enhanced the significance of such efforts to prevent any increase in non-Republican, non-white voters. Secretary of Commerce Wilbur Ross ordered adding a citizenship question to the census for the first time in half a century. Critics contended this move would diminish participation in the census, reducing its accuracy, while also reducing representation for areas with many immigrant residents, and possibly abetting deportations. The administration suspended its effort after the Supreme Court required further justification (Liptak 2019).

Along with immigration, policing is the policy area that most clearly invokes Trump's promises of protection for Americans portrayed as victims of violence. Here, too, the administration's policies have made clearer than Trump's rhetoric just whom to protected. Attorney General Sessions first ordered a sweeping review of federal studies of twenty city police departments' practices, hoping to reverse court-ordered consent decrees designed to limit racially discriminatory police abuses (Bosman and Smith 2017). Sessions also declined to open new investigations into police misconduct, despite continued police shootings of black men (Lowery 2018). He restored the transferal of surplus military equipment to local police forces, enabling them to create paramilitary units, as in Ferguson, Missouri (Viswanatha 2017). On his last day in office, Sessions issued a memo to prevent the Justice Department from using consent decrees to reform local police misconduct (Benner 2018).

Following persuasion by Kim Kardashian and Kanye West, and faced by overwhelming bipartisan support that included both the ACLU and the Koch brothers, Trump did endorse and sign the First Step Act (Bennett 2018). It provides sentencing relief for elderly inmates and those who received mandatory minimum sentences and authorizes rehabilitation programs. Trump has since often cited it, along with historically low African American unemployment, as evidence of his commitment to all Americans (Camera 2019; Trump 2019). However, Trump has not retreated from his "tough on crime" rhetoric that includes urging police to use "stop and frisk," tactics that have often been deployed in racially discriminatory ways
(Rucker 2018). His message has been that police should have greater freedom and greater weaponry to engage in the most controversial forms of policing.

Trump's appointment of Ben Carson as Secretary of Housing and Urban Development gave him an African American cabinet member. But under Trump and Carson, HUD moved quickly to end Obama-era efforts to promote racial integration in housing, as well as public housing services more generally. The Justice Department and HUD indicated that they would no longer file disparate impact suits to advance the Fair Housing Act's goal of fighting racial discrimination (Arpey 2017). HUD went further in 2019, proposing rules that would make it difficult if not impossible for regulators to find violations based simply on demonstrated disparate impact, without evidence of intentional discrimination (Vadum 2019). Carson's HUD has particularly targeted reversal of the Obama "Affirmatively Furthering Fair Housing" rule. It required localities to evaluate obstacles, including racial barriers, to housing choice in their jurisdiction, and to specify remedies as conditions of receiving federal funds. HUD suspended the rule in 2018 (Arpey 2017; Furman Center 2018). The upshot of these initiatives was to turn away from the pursuit of racially integrated housing and housing aid to the poor.

In his campaign, Trump championed vouchers for school choice as central to his civil rights agenda, though most leading civil rights groups oppose them. A champion of school choice, private schools, and weaker federal regulation, Betsy DeVos, is his Secretary of Education. His Education Department then created a grant program to promote vouchers. It rescinded guidance documents designed to prevent racial biases in school discipline, campus sexual misconduct, and discrimination against transgender students and students with disabilities. The Justice Department simultaneously cut back on efforts to continue court-ordered school desegregation.

Scholars have argued for decades that racial conservatism, along with economic conservatism, is strongly associated with opposition to social welfare programs (Gilens 1999). Here, too, the Trump administration has served its base. It has promoted state and national work requirements for benefits including Medicaid and SNAP, with some exemptions for areas predominantly populated by rural whites (Covert 2018). Its Federal Communications Commission is seeking to limit Lifeline, a program that assists low-income people, often indigenous communities, people of color, and disabled persons, to obtain phone and internet service (Morris 2018). All these policies signal which Americans the Trump administration most values.

\section{Trends in White Identity Mobilization}

It is too soon to have clear evidence that the rise of Trump has led more Americans to embrace white identities. Given 
his unpopularity, Trump's overall impact may be the reverse (Jardina, Kalmoe, and Gross 2019). But the studies already cited show that Trump's ascendancy has mobilized many white identifiers, making their policy preferences loom larger (Jardina 2019, 232-236). History also suggests that when those who are in a position to choose to identify as white, or to ally with those who identify as white, perceive whites as ascendant, many are likely to associate themselves with white identities and interests. In 2015, Pew data already indicated that most Americans with mixed backgrounds felt they had more in common with whites and generally identified as white, not as multiracial (Alba 2016). Trump's rhetoric portraying issues as zero-sum and promising protection from liberal elites, along with his policies designed to aid traditionalist groups, may make it seem even more in their interests to so identify. Many more Americans may then come to feel they will benefit from white protectionist policies.

The plausibility of this trajectory is evident in how Trump's success has emboldened white nationalists. These groups increased sharply after Barack Obama's election. They faded in Obama's latter years, as his agenda proved less race-conscious than they expected (Southern Poverty Law Center n.d.). The number and size of white nationalist organizations rose again under Trump (Ross, Hepp, and Gardner 2018; Parker and Barreto 2013). The Southern Poverty Law Center reports that white nationalist chapters grew from 100 in 2017 to 148 in 2018 and held more rallies (Beirich 2019). Many of these groups' rhetoric say less about the inferiority of non-whites than about the dangers of oppression that whites allegedly face-even as they still valorize white achievements (Beirich 2019). This adroit Trump-like shift enables them to fit into a conservative racial policy alliance that is redefining itself as focused on white protectionism.

Though many see colleges as bastions of liberalism, in June 2018 an Anti-Defamation League Study reported nearly 300 incidents of white supremacist groups distributing fliers and other materials on campuses in the previous academic year, an increase of 77\% (ADL Center on Extremism 2018). In many institutions, College Republicans are also resurging and embracing Trumpian ideology, proclaiming "we are the ones who are persecuted" in modern America (Steinmetz 2019). Most College Republicans distance themselves from white nationalism, but most endorse the need to protect against policies aimed at ending "white privilege" (Steinmetz 2019).

Trump's impact on racial identities and politics in America is also visible in the many Republican candidates who are emulating his style and substance (Herndon 2019). These include much-discussed figures like Roy Moore and Joe Arpaio, and others like Antonio Sabato, Jr., who ran against Maxine Waters for Congress by calling her a "hustler of hate," and Georgia gubernatorial candidate Michael Williams, who drove a "deportation bus" around the state; Brian Kemp countered by driving an armed pickup to "round up criminal illegals" (Johnson 2018). Overtly neo-Nazi and white supremacist candidates managed to win five GOP primaries in 2018 (Coaston 2018). So long as right-wing candidates did not openly identify as white supremacists, the Republican State Leadership Committee agreed to aid them, overlooking many close ties to white nationalist groups (Marans 2018).

\section{Conclusion}

There is, then, abundant evidence that Trump came to power with the aid of a galvanizing story of America that dismissed any need to address racial inequalities, or indeed, any focus on equality. More than any other candidate, he portrayed Americans as engaged in win-or-lose conflicts, and he promised to protect traditionalist Americans, especially conservative Christians who are predominantly white, against many forms of victimization, while also preserving the social programs his constituents favor.

Figure 1 documents that in office Trump has gone further, enacting policies that work with striking consistency in the directions needed for white protectionism in America. His administration has fought civil rights measures aimed at greater inclusion in public education, employment, and housing. It has ended efforts to curb racially discriminatory police abuses and student disciplinary practices. It has limited predominantly non-white immigration and favored barriers to participation by, primarily, nonwhite voters. It has reinvigorated white nationalist groups and inspired a plethora of Trump-like candidates. All these developments have the effect if not the intent of making many venues in America, and especially the electorate and the citizenry itself, if not great again, at least whiter again.

That outcome remains contested and uncertain. Many Trump-endorsed candidates lost in 2018. Many white Americans as well as citizens of color repudiate Trump and support removing him from office. Nonetheless, Trump's movement has shifted American politics toward a sharper clash between two altered race-conscious policy alliances, one now promising heightened protection for whites more explicitly, one becoming more assertive in favor of targeted aid to non-white groups. Still in doubt is how far this shift will go, and which policy alliance's narrative of America and Americans will hold the upper hand.

\section{References}

ADL Center on Extremism. 2018. "White Supremacist Propaganda Nearly Doubles on Campus in 2017-18 Academic Year." June 28 (https://www.adl.org/resources/ reports/white-supremacist-propaganda-nearly-doubleson-campus-in-2017-18-academic-year).

Alba, Richard. 2016. "The Likely Persistence of a White Majority.” American Prospect 27:67-71. 
Alexander, Harriet. 2018. “Trump Administration Sides against Harvard in Asian-American Affirmative Action Case." Daily Telegraph, August 18 (https:// www.telegraph.co.uk/news/2018/08/30/trumpadministration-sides-against-harvard-asian-americanaffirmative/).

Andrews, Jeff. 2018. "Trump Issues Executive Order on Work Requirements." Curbed, April 12 (https:// www.curbed.com/2018/4/12/17229656/trump-workrequirements-hud-housing-subsidies).

Anglin, Andrew. 2016. "Trump Retweets Two More White Genocide Accounts Back-to-Back.” Daily Stormer, January 25 (https://dailystormer.name/ happening-trump-retweets-two-more-white-genocideaccounts-back-to-back/).

Arpey, Conor. 2017. "The Business Implications of Disparate Impact's Uncertain Future.” BLR Buzz Blog, American University Business Law Review, April 17 (http://www.aublr.org/2017/04/businessimplications-disparate-impacts-uncertain-future/).

Baker, Peter. 2017. "President Backs a Plan to Curb Legal Migration." New York Times, August 3, A1.

Barr, William P.2019. "Remarks to the Law School and the de Nicola Center for Ethics and Culture at the University of Notre Dame." United States Department of Justice, October 11 (https://www.justice.gov/opa/ speech/attorney-general-william-p-barr-deliversremarks-law-school-and-de-nicola-center-ethics).

Bayer, Casey. 2017. "DeVos Rescinds Guidance Documents for Disabled Students: What Does It Mean?" Harvard Graduate School of Education, October 24 (https://www.gse.harvard.edu/news/17/10/ devos-rescinds-guidance-documents-disabled-studentswhat-does-it-mean).

Beinart, Peter, 2018. "Trump Shut Programs to Counter Violent Extremism.” The Atlantic, October 29 (https:// www.theatlantic.com/ideas/archive/2018/10/trumpshut-countering-violent-extremism-program/574237/).

Beirich, Heidi. 2019. "White Supremacy Flourishes amid Fears of Immigration and Nation's Shifting Demographics." Intelligence Report, Southern Poverty Law Center, February 20 (https://www.adl.org/ resources/reports/white-supremacist-propaganda-nearlydoubles-on-campus-in-2017-18-academic-year).

Benner, Katie. 2018. "Before Exiting, Sessions Sharply Curbs Agreements That Fight Police Abuse." New York Times, November 9, A15.

- 2020. "Office of Denaturalization Is Established." New York Times, February 27, A15.

Bennett, Brian. 2018. "How Unlikely Allies Got Prison Reform Done-With an Assist from Kim Kardashian West.” Time, December 21 (https:// time.com/5486560/prison-reform-jared-kushnerkim-kardashian-west/).
Berry, Kate. 2018. “CFPB's Mulvaney Strips His FairLending Office of Enforcement Powers." American Banker, February 1 (https://www.americanbanker.com/ news/cfpbs-mulvaney-strips-his-fair-lending-office-ofenforcement-powers).

Bonilla-Silva, Eduardo. 2017. Racism without Racists: Color-Blind Racism and the Persistence of Racism in America. New York: Rowman and Littlefield.

Bosman, Julie, and Mitch Smith. 2017. "Excessive Force Is Rife in Chicago, U.S. Review Finds." New York Times, January 14, A1.

Brennan Center for Justice. 2017. "Voting Laws Roundup 2017.” May 20 (https://www.brennancenter.org/ analysis/voting-laws-roundup-2017).

Brown, Andrew D. 2006. "A Narrative Approach to Collective Identities." Journal of Management Studies 43(4): 731-53.

Brownstein, Ronald. 2019. "The Limits of Trump's White Identity Politics." The Atlantic August 15.

Brubaker, Rogers. 2017. "Why Populism?" Theory and Society 46:357-85.

Bump, Philip 2017. "Roy Moore: America Was Great in Era of Slavery, Is Now 'Focus of Evil in the World.' Washington Post, December 8 (https:// www.washingtonpost.com/news/politics/wp/2017/12/08/ roy-moore-america-was-great-in-era-of-slavery-is-nowfocus-of-evil-in-the-world/?utm_term=.6de8e9e26e1c).

Camera, Lauren. 2019. "Trump to HBCU Leaders: No One Has Done More for You Than Me." U.S. News, September 10 (https://www.usnews.com/news/ education-news/articles/2019-09-10/trump-to-hbculeaders-no-one-has-done-more-for-you-than-me).

Cargle, Rachel Elizabeth. 2018. "How to Talk to Your Family About Racism on Thanksgiving." Harper's Bazaar, November 19 (https://www.harpersbazaar. com/culture/politics/a25221603/thanksgiving-dinnerconversation-how-to-talk-to-family-about-politics/).

Charland, Maurice. 1987. "Constitutive Rhetoric: The Case of the People Québecois." Quarterly Journal of Speech 73(2): 133-50.

Chen, Michelle, 2018. "Affirmative Action Is Under Attack." The Nation, August 31 (https://www.thenation.com/ article/affirmative-action-under-attack/).

Coaston, Jane, 2018. "Self-Described Nazis and White Supremacists Are Running as Republicans across the Country. The GOP Is Terrified.” Vox.com, July 9 (https://www.vox.com/2018/7/9/17525860/nazisrussell-walker-arthur-jones-republicans-illinois-northcarolina-virginia).

Cobb, Jelani. 2018. "Voter-Suppression Tactics in the Age of Trump." New Yorker, October 22 (https:// www.newyorker.com/magazine/2018/10/29/votersuppression-tactics-in-the-age-of-trump). 
Cohn, D’Vera. 2014. “Millions of Americans Changed Their Racial or Ethnic Identity from One Census to the Next." FactTank, May 5 (http://www.pewresearch.org/ fact-tank/2014/05/05/millions-of-americans-changedtheir-racial-or-ethnic-identity-from-one-census-tothe-next/).

Confessore, Nicholas. 2016. "For Whites Sensing Decline, Donald Trump Unleashes Words of Resistance." New York Times, July 14, A1.

Covert, Bryce. 2018. "The Not-So-Subtle Racism of Trump-Era 'Welfare 'Reform." New York Times, May 23 (https://www.nytimes.com/2018/05/23/ opinion/trump-welfare-reform-racism.html).

Crowley, Michael, and Maggie Haberman. 2019. “Trump Condemns White Supremacy but Stops Short of Major Gun Controls." New York Times, August 6, A1.

Davis, Julie Hirschfeld, and Maggie Haberman. 2017. "Trump Pardons Ex-Sheriff Seen as Migrant Foe." New York Times, August 6, A1.

Dawson, Michael C., and Megan Ming Francis. 2015. "Black Politics and the Neoliberal Racial Order." Public Culture 28(1): 23-62.

Democracy Fund Voter Study Group. 2017. "Executive Summary, " https://www.voterstudygroup.org/ publication/executive-summary, June.

Desjardins, Lisa. 2017. "How Trump Talks about Race." PBS News Hour, August 22 (https://www.pbs.org/ newshour/politics/every-moment-donald-trumpslong-complicated-history-race).

Dias, Elizabeth. 2017. "President Trump Lost a Fight to Allow Churches to Get More Involved in Politics." Time, December 15 (http://time.com/5067035/ president-trump-lost-a-fight-to-allow-churches-toget-more-involved-in-politics/).

Du Bois, W.E.B. 1920. Darkwater: Voices from Within the Veil. New York: Harcourt, Brace, and Howe.

Duggan, Andrew. 2015. "Among Republicans, GOP Candidates Better Known Than Liked." Gallup: Politics, July 24 (//news.gallup.com/poll/184337/ among-republicans-gop-candidates-better-knownliked.aspx?utm_source=Politics\&utm_medium = newsfeed\&utm_campaign=tiles).

Edwards-Levy, Ariel. 2016. "Nearly Half of Trump Voters Think Whites Face a Lot of Discrimination." Huffington Post, November 21 (https://www.huffpost. com/entry/discrimination-race-religion_n_5833761ee 4b099512f845bba).

Einbinder, Nicole. 2019. "The Trump Administration Has Actually Cut Government Resources to Fight White Supremacy and Domestic Terrorism." Business Insider, August 6 (https://www.businessinsider.com/ trump-cut-resources-fight-white-supremacy-domesticterrorism-2019-8).

Fadula, Lola, and Glenn Thrush. 2019. "Democrats Angered by HUD's Hiring of Trump Aide Who Quite
After Racist Posts.” New York Times July 1 (https:// www.nytimes.com/2019/07/01/us/politics/trumpaide-racism.html).

Faussett, Richard, and Michael Wines. 2018. "On Hunt for Illegal Voters, U.S. Subpoenas Election Data in North Carolina." New York Times, September 6, A16.

Felton, Emmanuel. 2017. "How the Federal Government Abandoned the Brown v. Board of Education Decision." The Hechinger Report, September 6 (http://hechingerreport.org/how-thefederal-government-abandoned-the-brown-v-boardof-education-decision/).

Fergus, Devin. 2018. Land of the Fee. New York: Oxford University Press.

Furman Center. 2018. "Policy Minute: HUD Delays Critical Fair Housing Requirement." The Stoop. NYU Furman Center, March 9 (http://furmancenter.org/ thestoop/entry/policy-minute-hud-delays-critical-fairhousing-requirement).

_. 2019. "Leading Housing Researchers Challenge Proposed Fair Housing Rule Change.” NYU Furman Center Press Release, October 17 (https:// furmancenter.org/news/press-release/leading-housingresearchers-challenge-proposed-fair-housing-rule-change).

Garcia, Jennifer R., and Christopher T. Stout. 2019.

"Responding to Racial Resentment: How Racial Resentment Influences Legislative Behavior.” Political Research Quarterly. https://doi.org/10.1177\% 2F1065912919857826.

Garcia-Navarro, Lulu. 2019. "Stephen Miller and 'The Camp of the Saints': A White Nationalist Reference." NPR News, November 19.

Gest, Justin. 2018. The White Working Class: What Everyone Needs to Know. New York: Oxford University Press.

Gest, Justin, Tyler Reny, and Jeremy Mayer. 2018. "Roots of the Radical Right: Nostalgic Deprivation in the United States and Britain." Comparative Political Studies 51(13): 1694-719.

Gladstone, Rick, and Satoshi Sugiyama. 2018. "Trump's Travel Ban: How It Works and Who Is Affected." New York Times, July 2, A8.

Golub, Mark. 2018. Is Racial Equality Unconstitutional? New York: Oxford University Press.

Gonyea, Don. 2017. "Majority of White Americans Say They Believe Whites Face Discrimination.” NPR News, October 24 (https://www.npr.org/2017/10/24/ 559604836/majority-of-white-americans-think-theyrediscriminated-against).

Green, Erica L., Matt Apuzzo, and Katie Benner. 2018. "Trump Officials Reverse Obama’s Policy on Affirmative Action in Schools." New York Times, July 4, A1.

Green, Jon, and Sean McElwee. 2018. "The Differential Effects of Economic Conditions and Racial Attitudes in the Election of Donald Trump."Perspectives on Politics 17(2): 358-69. 
Gutierrez, Gabe. 2018. "Sent by Trump, Soldiers Arrive at Border as Migrant Caravan in Mexico Pushes North." NBC News, November 3 (https://www.nbcnews.com/ news/us-news/sent-trump-soldiers-arrive-border-migrantcaravan-pushes-north-n930751).

Hannah-Jones, Nikole. 2017. "The Resegregation of Jefferson Count." New York Times Magazine, September 6 (https://www.nytimes.com/2017/09/06/ magazine/the-resegregation-of-jefferson-county.html).

Hatewatch. 2018. "Stephen Miller: A Driving Force behind the Muslim Ban and Family Separation Policy." Southern Poverty Law Center, June 21 (https:// www.splcenter.org/hatewatch/2018/06/21/stephenmiller-driving-force-behind-muslim-ban-and-familyseparation-policy).

Hayes, Christal. 2018. "Here Are 10 Times President Trump's Comments Have Been Called Racist." USA Today, August 14 (https://www.usatoday.com/story/ news/politics/onpolitics/2018/08/14/times-presidenttrump-comments-called-racist/985438002/).

Herndon, Astead W. 2018. "Accusations of Voter Suppression as Some in Georgia Begin to Cast Their Ballots." New York Times, October 20, A15.

_. 2019. "'Witch Hunts' and 'Fake News': Trump Grievances Go Local." New York Times, March 17, A20.

Holmes, Jack. 2017. "Trump's Disgusting Retweets Suggest a Larger Problem Is Brewing." Esquire.com, November 29 (https://www.esquire.com/newspolitics/a13974149/trump-retweet-britain-first/).

Hood, Gregory. 2019. "Western Civilization Is White Civilization.” American Renaissance, January 21(https:// www.amren.com/commentary/2019/01/westerncivilization-is-white-civilization/).

Hughey, Matthew W. 2016. "Hegemonic Whiteness: From Structure and Agency to Identity Allegiance." In The Construction of Whiteness: An Interdisciplinary Analysis of Race Formation and the Meaning of a White Identity, ed. Stephen Middleton, David R. Roediger, and Donald M. Shaffer, 212-233. Jackson: University Press of Mississippi.

Ingraham, Christopher. 2017. "Here Are the First 10 Members of Trump's Voting Commission." Washington Post, July 6 (https://www.washingtonpost. com/news/wonk/wp/2017/07/06/here-are-the-first-10members-of-trumps-voter-fraud-commission/?utm_ term=.abadedb44f38).

Ivarsflaten, Elizabeth. 2008. "What Unites Right-Wing Populists in Western Europe? Re-Examining Grievance Mobilization Models in Seven Successful Cases." Comparative Political Studies 41(1): 3-23.

Jamerson, Joshua. 2019. "Reparations for Slavery, Shelved for Decades, Are on the Table for the 2020 Election." Wall Street Journal, April 12 (https://www.wsj.com/ articles/reparations-for-slavery-shelved-for-decades-ison-the-table-for-2020-election-11554989520).
Jardina, Ashley 2019. White Identity Politics. New York: Cambridge University Press.

Jardina, Ashley, Nathan Kalmoe, and Kimberly Gross. 2019. "Disavowing White Identity: How Trump's Election Made White Racial Identity Distasteful." Presented at the 2019 Annual Meeting of the American Political Science Association, Washington, DC, August 29-September 1.

Jardina, Ashley, and Michael Traugott. 2019. "The Genesis of the Birther Rumor: Partisanship, Racial Attitudes, and Political Knowledge." Journal of Race, Ethnicity and Politics 4(1): 60-80.

Jaschik, Scott. 2018. "Kavanaugh Evades Questions on Affirmative Action in Higher Education." InsideHigherEd, November 14 (https://www.insidehighered.com/ quicktakes/2018/09/14/kavanaugh-evades-questionsaffirmative-action).

Johnson, Jenna, 2018. "With Trump in the White House, Candidates Who Sound Like Him Hit the Campaign Trail." Washington Post, July 16 (https:// www.washingtonpost.com/politics/with-trump-in-thewhite-house-candidates-who-sound-like-him-hit-thecampaign-trail/2018/07/15/2ff71b5a-86c5-11e8-8553a3ce89036c78_story.html?utm_term=.ffc2c685f2d9).

Kinder, Donald R., and Lynn M. Sanders. 1994. Divided by Color. Chicago: University of Chicago Press.

King, Desmond. 2007. Separate and Unequal: African Americans and the US Federal Government. New York: Oxford University Press.

King, Desmond. and Rogers M. Smith. 2005. "Racial Orders and American Political Development." American Political Science Review 99(1): 75-96.

- 2011. Still A House Divided. Princeton, NJ: Princeton University Press.

—. 2014. "Without Regard to Race': Critical Ideational Development in Modern American Racial Politics." Journal of Politics 76(4): 958-71.

Kopan, Tal. 2016. "Donald Trump Retweets 'White Genocide' Twitter User," CNN Politics, January 22 (https://www.cnn.com/2016/01/22/politics/ donald-trump-retweet-white-genocide/index.html).

Leadership Conference on Civil and Human Rights. N.d. "Trump Administration Civil and Human Rights Rollbacks." https://civilrights.org/trump-rollbacks/.

Levine, Mike. 2016. "What Jeff Sessions Has Said about Race and Civil Rights." ABCNews, November 18 (https://abcnews.go.com/Politics/jeff-sessions-racecivil-rights/story?id=43633501).

Lieberman, Robert C., Suzanne Mettler, Thomas B. Pepinsky, Kenneth M. Roberts, and Richard Valelly. 2019. "The Trump Presidency and American Democracy: A Historical and Comparative Analysis." Perspectives on Politics 17(2): 470-79.

Liptak, Adam. 2018. "Supreme Court Upholds Purge of Ohio Voters." New York Times, June 12, A1. 
—_. 2019. "Supreme Court Leaves Census Question on Citizenship in Doubt." New York Times, June 27 (https:/www.nytimes.com/2019/06/27/us/politics/ census-citizenship-question-supreme-court.html).

Lopez, German. 2019. "Donald Trump's Long History of Racism, from the 1970s to 2019." Vox, February 14 (https://www.vox.com/2016/7/25/12270880/donaldtrump-racist-racism-history).

Lopez Bunyasi, Tehama. 2019. "The Role of Whiteness in the 2016 Presidential Primaries." Perspectives on Politics 17(3): 679-98.

Lowery, Wesley, 2018. "Police Are Still Killing Black People. Why Isn't It News Anymore?” Washington Post, March 16 (https://www.washingtonpost.com/outlook/ police-are-still-killing-black-people-why-isnt-it-newsanymore/2018/03/12/df004124-22ef-11e8badd-7c9f29a55815_story.html?utm_term= .d3149a33c47f).

Mann, Ted. 2017. "White House Won't Require Firms to Report Pay by Gender, Race.” Wall Street Journal, August 29 (https://www.wsj.com/articles/white-housewont-require-firms-to-report-pay-by-gender-race1504047656).

Marans, Daniel 2018. “GOP State Lawmakers Pal Around with White Supremacists. Party Group Backs Them Anyway." HuffPost, October 22 (https://www.huffpost. com/entry/republican-state-lawmakers-white-nationalistsrslc-silent_n_5bcd82e4e4b0a8f17eee0a1d).

Margalit, Yotam. 2012. "Lost in Globalization:

International Economic Integration and the Sources of Populist Discontent." International Studies Quarterly 56(3): 484-500.

Masuoka, Natalie. 2017. Multiracial Identity and Racial Politics in the United States. New York: Oxford University Press.

Mazzei, Patricia. 2019. "Ex-Felons in Florida Have the Right to Vote, but It's Not That Simple." New York Times, May 4, A11.

Meckler, Laura, and Devlin Barrett, 2019.

"Trump Administration Considers Rollback of AntiDiscrimination Rules." Washington Post, January 3 (https://www.washingtonpost.com/local/education/ trump-administration-considers-rollback-of-antidiscrimination-rules/2019/01/02/f96347ea-046d11e9-b5df-5d3874f1ac36_story.html?utm_term= .dabb0a64070e).

Mendelberg, Tali. 2001. The Race Card: Campaign Strategy, Implicit Messages, and the Norm of Equality. Princeton, NJ: Princeton University Press.

Miroff, Nick, 2018. "Family Ties Drive U.S. Immigration. Why Trump Wants to Break the 'Chains.'” Washington Post, January 2 (https:// www.washingtonpost.com/world/national-security/ how-chain-migration-became-a-target-in-trumpsimmigration-agenda/2018/01/02/dd30e034-efdb- 11e7-90ed-77167c6861f2_story.html?utm_term= .cc0823472c94).

Moreau, Julie. 2018. “Transgender Workers Not Protected by Civil Rights Law, DOJ Tells Supreme Court." NBC News, October 25 ((https://www.nbcnews.com/feature/ nbc-out/transgender-workers-not-protected-civil-rightslaw-doj-tells-supreme-n924491).

Morris, Sarah, 2018. "All I Want This Holiday Season Is For FCC's Terrible Lifeline Proposal to Go Away." Slate, December 27 (https://slate.com/technology/ 2018/12/fcc-lifeline-reform-proposal.html).

Mutz, Diana C. 2018. "Status Threat, Not Economic Hardship, Explains the 2016 Presidential Vote." PNAS 115(19): E4330-E4339.

National Immigration Law Center. 2019. "Status of Current DACA Litigation.” February 7 (https:// www.nilc.org/issues/daca/status-current-daca-litigation/).

Norton, Michael I., and Samuel R. Sommers. 2011. "Whites See Racism as a Zero-Sum Game that They Are Now Losing." Perspectives on Psychological Science 6(3): 215-18.

Office of Civil Rights, Department of Education. N.d. "Sex Discrimination: Policy Guidance." (https:// www2.ed.gov/about/offices/list/ocr/frontpage/faq/rr/ policyguidance/sex.html).

Office of Special Education and Rehabilitative Services. 2018. "Regulation Postponed Two Years to Insure Effective Implementation.” IDEA, July 3 (https:// sites.ed.gov/idea/regulation-postponed-two-years-toensure-effective-implementation/).

Omi, Michael, and Howard Winant. 1986. Racial Formation in the United States. New York: Routledge.

On the Issues. 2016. "Donald Trump on Social Security." (http://www.ontheissues.org/2016/Donald_Trump_ Social_Security.htm).

Osnos, Evan. 2015. "The Fearful and the Frustrated: Donald Trump's Nationalist Coalition Takes ShapeFor Now." New Yorker, August 31 (https://www. newyorker.com/magazine/2015/08/31/the-fearfuland-the-frustrated).

Paletta, Damien, Mike DeBonis, and John Wagner, 2019. "Trump Declares National Emergency on Southern Border in Bid to Build Wall." Washington Post, February 15 (https://www.washingtonpost. $\mathrm{com} /$ politics/trumps-border-emergency-thepresident-plans-a-10-am-announcement-in-therose-garden/2019/02/15/f0310e62-3110-11e986ab-5d02109aeb01_story.html?utm_term= .c469303871c1).

Parker, Christopher S., and Matt A. Barreto, 2013. Change They Can't Believe In. Princeton, NJ: Princeton University Press.

Perry, Samuel L. and Andrew L. Whitehead. 2019. "Christian America in Black and White: Racial Identity, Religious-National Group Boundaries, 
and Explanations for Racial Inequality." Sociology of Religion: A Quarterly Review 80(3): 277-98.

Public Religion Research Institute (PRRI). 2018. "Partisan Polarization Dominates Trump Era: Findings from the 2018 American Values Survey." October 19 (https://www.prri.org/research/partisan-polarizationdominates-trump-era-findings-from-the-2018-americanvalues-survey/).

Public Interest Legal Foundation. 2018a. "PILF Commends DOJ Vote Monitoring Plan." November 5 (https://publicinterestlegal.org/blog/pilf-commendsdoj-vote-monitoring-plan/),

_ 2018b. "PILF to SCOTUS: Census Needs Citizenship Question.” November 13 (https:// publicinterestlegal.org/blog/pilf-to-scotus-2020census-needs-citizenship-question/).

Raymond, Laurel. 2017. “Trump Administration Eliminates Funding for Group Countering White Nationalism." ThinkProgress, June 23 (https:// thinkprogress.org/white-nationalism-group-fundingf1d35fb5604e/).

Reilly, Ryan J. 2019. "5 Years after Ferguson, the Justice Department Has All but Ended Federal Police Reform." Huffington Post, August 9 (https://www.huffpost.com/ entry/ferguson-justice-department-police-reformtrump-pattern-or-practice_n_5d4b18b3e4b00 66eb70bad87).

Rein, Lisa. 2018. "Don't Condemn White Nationalists, Veterans Affairs' Diversity Chief Was Told after Charlottesville, Emails Show." Washington Post, December 5 (https://www.washingtonpost.com/ politics/dont-condemn-white-nationalists-veteransaffairs-diversity-chief-was-told-after-charlottesvilleemails-show/2018/12/05/fbff66ce-f41d-11e8-aeeab85fd44449f5_story.html?utm_term=.45b705c02a1d).

Reitman, Janet. 2018. "U.S. Law Enforcement Failed to See the Threat of White Nationalism. Now They Don't Know How to Stop It." New York Times Magazine, November 11, 38.

Rogers, Katie, and Jason DeParle. 2019. "The White Nationalist Websites Cited by Stephen Miller." New York Times, November 18 (https:// www.nytimes.com/2019/11/18/us/politics/stephenmiller-white-nationalism.html).

Ross, Megan, Brooks Hepp, and Kianna Gardner, 2018.

"White Extremist Groups Are Growing-and Changing." Center for Public Integrity, September 5 (https://publicintegrity.org/federal-politics/whiteextremist-groups-are-growing-and-changing/).

Rucker, Philip. 2018. "Trump Says Chicago Police Should Use 'Stop and Frisk' Tactics to Curb Shootings." Washington Post, October 8 (https://www. washingtonpost.com/politics/trump-says-chicago-policeshould-use-stop-and-frisk-tactics-to-curb-shootings/ 2018/10/08/a4afaaa0-cb0f-11e8-a3e6-44daa3d35ede_ story.html?utm_term=.2a583df23974).

Sacchetti, Maria. 2017. "Immigration Judges Say Proposed Quotas from Justice Dept. Threaten Independence." Washington Post, October 12 (https://www.washingtonpost.com/local/immigration/ immigration-judges-say-proposed-quotas-from-justicedept-threaten-independence/2017/10/12/3ed86992aee1-11e7-be94-fabb0f1e9ffb_story.html?utm_term= $.834 \mathrm{c} 31 \mathrm{acfd} 7 \mathrm{~d})$.

Sacchetti, Maria, Felicia Sonmez, and Nick Miroff, 2019.

"Trump Tightens Asylum Rules, Will Make Immigrants Pay Fees to Seek Humanitarian Refuge." Washington Post, April 30 (https://www.washingtonpost.com/politics/ trump-issues-memo-calling-for-changes-to-handling-ofasylum-cases/2019/04/29/df41b5f2-6adb-11e9-be3a33217240a539_story.html?utm_term=.9c021658e6f9).

Salozar, Carolyn, 2019. "Kavanaugh Slams 'Pure Discrimination' against Churches as Court Declines to Hear Religious Liberty Case.” Fox News, March 4 (https://www.foxnews.com/politics/kavanaugh-slamspure-discrimination-against-churches-as-courtdeclines-to-hear-religious-liberty-case).

Sanders, Ron, 2018. "Inactive Registered Voters No Longer Purged in Kentucky.” SurfKY News Group, November 14 (https://www.surfky.com/index.php/ ohio/179-news/kentucky/130688-inactive-registeredvoters-no-longer-purged-in-kentuck).

Sankin, Aaron, and Will Carless. 2018. "President Trump Is Pushing White Nationalist Ideas into the Mainstream." Washington Post, August 24 (https:// www.washingtonpost.com/outlook/2018/08/24/ president-trump-is-pushing-white-nationalist-ideasinto-mainstream/?utm_term =.d23863ed3b67).

Savage, Charlie 2017. "Justice Dept. to Take on Affirmative Action in College Admissions." New York Times, August 2, A1.

Schaffner, Brian F., Matthew MacWilliams, and Tatishe Nteta. 2018. "Understanding White Polarization in the 2016 Vote for President: The Sobering Role of Racism and Sexism." Political Science Quarterly 133(1): 9-34.

Schmidt, Samantha 2019. "'Victory for Equal Pay': Judge Rules Trump Administration Must Require Companies to Report Pay by Gender, Race." Washington Post, March 5 (https://www.washingtonpost.com/dc-mdva/2019/03/05/victory-equal-pay-judge-rules-trumpadministration-must-require-companies-report-payby-gender-race/?utm_term=.6eefb8fd8010).

Schnurer, Eric. 2017. "The Rise of Zero-Sum Politics." U.S. News, September 14 (https://www.usnews.com/ opinion/thomas-jefferson-street/articles/2017-09-14/ donald-trump-and-the-rise-of-zero-sum-politics).

Schroeder, Robert. 2016. "Trump Has Gotten Nearly \$3 Billion in 'Free' Advertising." MarketWatch, May 6 
(https://www.marketwatch.com/story/trump-hasgotten-nearly-3-billion-in-free-advertising-2016-05-06).

Scott, Eugene Scott. 2018. "Trump Said It Is 'Racist' to Ask Him about His Nationalism. Here's Why It's Necessary." Washington Post, November 8 (https:// www.washingtonpost.com/politics/2018/11/08/ trump-said-it-is-racist-ask-him-about-his-nationalismheres-why-its-necessary/?utm_term=.3b7b570f57c1).

Serwer, Adam. 2017. “Jeff Sessions' Unqualified Praise for a 1924 Immigration Law." The Atlantic, January 10 (https://www.theatlantic.com/politics/archive/2017/ 01/jeff-sessions-1924-immigration/512591/).

Sessions, Jefferson, 2018. "Remarks at the Department of Justice's Religious Liberty Summit." United States Department of Justice, July 30 (https://www.justice.gov/ opa/speech/attorney-general-sessions-delivers-remarksdepartment-justice-s-religious-liberty-summit).

Sides, John, Michael Tesler, and Lynn Vavreck. 2017. "The 2016 Election: How Trump Lost and Won." Journal of Democracy 28(2): 34-44.

\section{- 2018. Identity Crisis: The 2016 Election and the} Battle for the Meaning of America. Princeton, NJ: Princeton University Press.

- 2019. The 2016 Presidential Campaign and the Battle for the Meaning of America. Princeton, NJ: Princeton University Press.

Smith, David. 2017. "Q\&A: What Are Trump and the White House's Links to the Far Right?" The Guardian, August 14 (https://www.theguardian.com/us-news/ 2017/aug/14/donald-trump-steve-bannon-breitbartnews-alt-right-charlottesville).

Smith, Rogers M. 2003. Stories of Peoplehood: The Politics and Morals of Political Membership. New York: Cambridge University Press.

- 2015. Political Peoplehood: The Roles of Values, Interests, and Identities. Chicago: University of Chicago Press.

Sniderman, Paul, and Edward Carmines, 1997. Issue Evolution. Princeton, NJ: Princeton University Press.

Southern Poverty Law Center. N.d. "White Nationalist." (https://www.splcenter.org/fighting-hate/extremistfiles/ideology/white-nationalist).

Stein, Letitia, 2018. "Politics Clouds Felon Voting Rights Restoration in Florida." Reuters, December 15 (www.reuters.com/article/us-usa-florida-felons/politicscloud-felon-voting-rights-restoration-in-floridaidUSKBN1OE0C2).

Steinmetz, Katy. 2019. “The Most Hated Person on Campus': Why Some College Republicans Are Channelling Trump." Time. (http://time.com/themost-hated-person-on-campus-why-some-collegerepublicans-are-channeling-donald-trump/).

Strauss, Valerie, Danielle Douglas-Gabriel, and Moriah Balingit. 2018. "DeVos Seeks Cuts from Education Department to Support School Choice." Washington
Post, February 13 (www.washingtonpost.com/news/ education/wp/2018/02/12/devos-seeks-massive-cutsfrom-education-department-to-support-school-choice/? utm_term=.fb52fe56d13f).

Summers, Madison. 2019. "Cruz Addresses the 'Overheated' Rhetoric between POTUS and the Freshmen Democrat 'Squad.” IJR (Independent Journal Review), August 1 (https://ijr.com/cruz-addressesoverheated-rhetoric-potus-freshmen-dems/).

Tackett, Michael, and Michael Wines. 2018. "Trump Shutters His Commission on Voter Fraud." New York Times, January 4, A1.

Tesler, Michael. 2012. "The Spillover of Racialization into Health Care: How President Obama Polarized Public Opinion by Race and Racial Attitudes." American Journal of Political Science 56(3): 690-704.

- 2013. "The Return of Old Fashioned Racism to White Americans' Partisan Preferences in the Early Obama Era." Journal of Politics 75(1): 110-123.

- 2016. Post-Racial or Most Racial? Politics and Race in the Obama Era. Chicago: University of Chicago Press.

- 2017. "Trump Voters Think African Americans Are Much Less Deserving Than 'Average Americans."' Huffington Post, December 20 (https://www.huffpost. com/entry/trump-voters-think-africa_b_13732500).

Thompson, Andrew. 2018. "The Measure of Hate on 4Chan." Rolling Stone, May 10 (https://www. rollingstone.com/politics/politics-news/the-measureof-hate-on-4chan-627922/)

Thurston, Chloe N. 2018. At the Boundaries of Homeownership. New York: Cambridge University Press. Torbati, Yeganeh, 2018. "Trump Administration Bars Haitians from U.S. Visas for Low-Skilled Work." Reuters, January 17 (www.reuters.com/article/us-usaimmigration-haiti/trump-administration-bars-haitiansfrom-u-s-visas-for-low-skilled-work-idUSKBN1F702O? feedType=RSS\&feedName=politicsNews).

Trump, Donald J. 2015. "Remarks Announcing Candidacy for President in New York City." June 16, The American Presidency Project (http://presidency. proxied.lsit.ucsb.edu/ws/index.php?pid=110306).

— 2016a. "Remarks on Foreign Policy at the National Press Club in Washington, D.C.” April 27, The American Presidency Project (http://presidency. proxied.lsit.ucsb.edu/ws/index.php?pid=117813).

- 2016b. "Remarks in Virginia Beach, Virginia,"

July 11, The American Presidency Project (https:// www.presidency.ucsb.edu/documents/remarksvirginia-beach-virginia-0).

_. 2016c. "Address Accepting the Presidential Nomination at the Republican National Convention in Cleveland, Ohio." July 21, The American Presidency Project (https://www.presidency.ucsb.edu/ 
documents/address-accepting-the-presidentialnomination-the-republican-national-conventioncleveland).

_. 2016d. "Remarks at Youngstown State University in Youngstown, Ohio." August 15, The American Presidency Project (https://www.presidency.ucsb.edu/ documents/remarks-youngstown-state-universityyoungstown-ohio).

_. 2016e. "Remarks at the Washington County Park Fair in West Bend, Wisconsin." August 16, The American Presidency Project (https://www.presidency. ucsb.edu/documents/remarks-the-washington-countyfair-park-west-bend-wisconsin).

_ 2016f. "Remarks at the Summit Sports and Ice Complex in Dimondale, Michigan." August 19, The American Presidency Project (http://presidency. proxied.lsit.ucsb.edu/ws/index.php?pid=123197). _. 2016g. "Remarks at Great Faith International Ministries in Detroit, Michigan." September 3, The American Presidency Project (https:// www.presidency.ucsb.edu/documents/remarks-greatfaith-international-ministries-detroit-michigan).

_ 2016h. "Remarks at the Cleveland Arts and Sciences Academy in Cleveland, Ohio." September 8, The American Presidency Project (https://www.presidency. ucsb.edu/documents/remarks-the-cleveland-arts-andsocial-sciences-academy-cleveland-ohio).

_ . 2016i. "Remarks to the 11th Annual Values Voter Summit in Washington, D.C. Omni Shoreham Hotel." September 9, The American Presidency Project (https:// www.presidency.ucsb.edu/documents/remarks-the11th-annual-values-voter-summit-washington-dcomni-shoreham-hotel-washington).

_. 2016j. "Remarks at a Rally at Sun Center Studios in Chester Township, Pennsylvania." September 22, The American Presidency Project (https://www.presidency. ucsb.edu/documents/remarks-rally-sun-center-studioschester-township-pennsylvania).

_. 2016k. "Remarks at the South Florida Fair Expo Center in West Palm Beach, Florida." October 13, The American Presidency Project (https://www. presidency. ucsb.edu/documents/remarks-the-south-florida-fairexpo-center-west-palm-beach-florida).

_ 2018. "Congresswoman Maxine Waters." June 25 (https://twitter.com/realdonaldtrump/status/ 1011295779422695424 ? lang=en).

—. 2019. "Remarks by President Trump at 2019 Second Step Presidential Justice Forum." October 25 (https://www.whitehouse.gov/briefings-statements/ remarks-president-trump-2019-second-step-presidentialjustice-forum-columbia-sc/).

Ujifusa, Andrew. 2018. "Betsy DeVos Revokes Obama Discipline Guidance Designed to Protect Students of Color." Education Week: Politics K-12, December 21 (http://blogs.edweek.org/edweek/campaign-k-12/2018/ 12/betsy_devos_revokes_obama_discipline_guidance_ students_of_color_protect.html).

Vadum, Matthew. 2019. "Ben Carson Seeks Fairer, More Efficient Disparate Impact Rules.” Washington Times, October 30 (https://www.theepochtimes.com/bencarson-seeks-fairer-more-efficient-disparate-impactrule_3132184.html).

Viswanatha, Aruna, 2017. "Trump Administration Lifts Obama's Ban on Military Surplus Gear Going to Police." Wall Street Journal, August 28 (www.wsj.com/ articles/trump-administration-allows-police-agenciesto-get-surplus-military-gear-in-reversal-of-obama-rule1503934284).

Weber, Travis. 2019. "Justices Alito, Thomas, Gorsuch, and Kavanaugh: We See Religious Freedom Problems with Coach Kennedy Case." Family Research Council, January 22 (https://www.frcblog.com/2019/01/ justices-alito-thomas-gorsuch-and-kavanaugh-we-seereligious-freedom-problems-coach-kennedy-case/).

Wessler, Seth Freed. 2018. "Is Denaturalization the Next Front in the Trump Administration's War on Immigration?" New York Times Magazine, December 19, 36.

Wines, Michael. 2018. "U.S. Shifts Stance on Voting Rights, Embracing Limits." New York Times, August 13, A1. 